\title{
MOTION COMPENSATION STRATEGY OF PRESCHOOLERS COPING WITH TASKS OF STRIDE LENGTH CHANGES AND CURVE TURNINGS: IN TERMS OF CENTRE OF MASS
}

\author{
Mingyu HU ${ }^{1}$, Quting HUANG ${ }^{1}$, Bo XU ${ }^{1}$, Wuyong $\mathrm{CHEN}^{1}$, Jianxin WU ${ }^{2}$, Jin $\mathrm{ZHOU}^{1,2^{*}}$ \\ ${ }^{1}$ National Engineering Laboratory for Clean Technology of Leather Manufacture, Sichuan University; Chengdu 610065, P. R. \\ China \\ ${ }^{2}$ Science Lab, Zhejiang red dragonfly footwear Co., LTD., Zhejiang Province, Wenzhou 325100, P. R. China
}

Received: 13.09.2018

Accepted: 07.02.2019

https://doi.org/10.24264/Ifj.19.1.3

\begin{abstract}
MOTION COMPENSATION STRATEGY OF PRESCHOOLERS COPING WITH TASKS OF STRIDE LENGTH CHANGES AND CURVE TURNINGS: IN TERMS OF CENTRE OF MASS

ABSTRACT. The purpose of this study was first to disclose motion compensation strategy of healthy preschoolers according to evaluate how the stride length changes and curve turnings affected their Centre of Mass (CoM) performances; and then to comprehend the process of children develop in motion. Ten healthy children aged around 6 and 9 adults aged 23-47 were recruited in this study. The CoM was calculated based on four key markers in pelvis and its trajectory in five tasks including the stride length changes (short stride, straight walking and long stride) and curve turnings $\left(0^{\circ}-30^{\circ}-60^{\circ}\right)$ were first recorded; and then variables such as trajectory of CoM in sagittal and coronal plane, Unit of Energy (uEN), Energy Kinetic (uEk) and Gravitational Potential Energy (uEg) in the critical gait period were analyzed. Results show that as the stride length increase, child accordingly enlarged their motion range of CoM both in mediolateral and vertical direction to assist the wholebody movement; meanwhile, children's uEN increased as the stride length prolonged. Further, since $10 \% \mathrm{GC}$, child's CoM shifted gradually to the curving direction (right) as curve turning angle aggregated; while, dramatic change occurred at $60 \% \mathrm{GC}$, where a larger CoM deviation was found in $60^{\circ}$ than that of $30^{\circ}$. The uEN of children was low before $60 \% \mathrm{GC}$, but it raised prominently after $60 \% \mathrm{GC}$. Overall, adult-like CoM were partly found in healthy preschoolers when coping with varied gait tasks, however distinctions existed which demonstrated that compensative strategies of those children were still developing.

KEY WORDS: center of mass, children development, compensative strategy, stride length, curve turning
\end{abstract}

\section{STRATEGIA DE COMPENSARE A MIŞCĂRII LA PREŞCOLARI LA MODIFICAREA LUNGIMII PASULUI ŞI LUAREA CURBELOR: REFERITOR LA CENTRUL DE MASĂ}

REZUMAT. Scopul acestui studiu a fost acela de a descoperi mai întâi strategia de compensare a mişcării la preşcolarii sănătoşi, pentru a evalua modul în care modificarea lungimii pasului şi luarea curbelor au afectat performanţele Centrului de masă (CoM); şi apoi de a înţelege procesul de dezvoltare a mişcării la copii. În acest studiu au fost recrutaţi zece copii sănătoşi cu vârsta de aprox. 6 ani şi nouă adulţi cu vârsta cuprinsă între 23-47 ani. CoM a fost calculat pe baza a patru markeri cheie în regiunea pelvisului şi traiectoria acestora pe măsura efectuării a cinci acţiuni, printre care modificarea lungimii pasului (pas scurt, mişcare dreaptă şi pas lung) şi luarea curbei $\left(0^{\circ}-30^{\circ}-60^{\circ}\right)$ care au fost înregistrate mai întâi; apoi s-au analizat variabile precum traiectoria CoM în plan sagital şi coronal, Unitatea de Energie (uEN), Energia Kinetică (uEk) şi Energia Potenţialului Gravitaţional (uEg) în perioada critică a mersului. Rezultatele arată că, pe măsură ce creşte lungimea paşilor, copilul îşi măreşte intervalul de mişcare a CoM, atât în direcţie mediolaterală, cât şi verticală, pentru a ajuta circulaţia întregului corp; în acelaşi timp uEN al copiilor a crescut pe măsură ce s-a mărit lungimea paşilor. Mai mult, la 10\% GC, CoM al copiilor s-a mutat treptat în direcţia de curbare (dreapta), pe măsură ce unghiul curbei s-a mărit; în timp ce o schimbare dramatică a avut loc la 60\% GC, unde s-a constatat o deviaţie mai mare a CoM la $60^{\circ}$ comparativ cu $30^{\circ}$. uEN al copiilor a scăzut înainte de $60 \%$ GC, dar a crescut vizibil după $60 \%$ GC. În ansamblu, un CoM asemănător celui întâlnit la adulţi a fost întâlnit parţial la preşcolari sănătoşi atunci când aceştia s-au confruntat cu diverse acţiuni legate de mers, cu toate acestea au existat distincţii care au demonstrat că strategiile compensatorii ale acelor copii erau încă în curs de dezvoltare. CUVINTE CHEIE: centrul de masă, dezvoltarea copiilor, strategie de compensare, lungimea pasului, luarea curbelor

\section{STRATÉGIE DE COMPENSATION DU MOUVEMENT DES PRÉSCOLAIRES DANS LE CHANGEMENT DE LA LONGUEUR DES FOULÉES ET LES TRAJECTOIRES COURBES: À PROPOS DU CENTRE DE MASSE}

RÉSUMÉ. Le but de cette étude était d'abord de découvrir la stratégie de compensation du mouvement des préscolaires en santé afin d'évaluer comme les changements de la longueur des foulées et la marche sur des trajectoires courbes sur les performances du centre de la masse (CoM); et ensuite pour comprendre le processus de développement du mouvement chez les enfants. Dix enfants en bonne santé âgés environ 6 ans et neuf adultes de 23 à 47 ans ont été recrutés dans cette étude. Le CoM a été calculé à partir de quatre marqueurs clés dans la région du pelvis et sa trajectoire dans cinq actions, notamment les changements de longueur de foulée (foulée courte, marche droite et foulée longue) et les trajectoires courbes $\left(0^{\circ}-30^{\circ}-60^{\circ}\right)$ ont été enregistrés pour la première fois, et ensuite on a analysé des variables telles que la trajectoire de CoM dans le plan sagittal et coronal, l'unité d'énergie (uEN), l'énergie cinétique (uEk) et l'énergie potentielle gravitationnelle (uEg) dans la période de marche critique. Les résultats montrent que, à mesure que la longueur de la foulée augmente, l'enfant élargit en conséquence sa plage de mouvements de CoM à la fois dans la direction médiolatérale et verticale afin d'aider le mouvement du corps entier; dans le même temps, la valeur uEN chez les enfants augmentait à mesure que la foulée se prolongeait. En outre, depuis $10 \%$ GC, le CoM de l'enfant est passé progressivement dans la direction de la courbe (à droite) à mesure que l'angle de rotation de la courbe s'agrégeait; tandis que, un changement dramatique s'est produit à $60 \% \mathrm{GC}$, où un écart de CoM plus grand a été trouvé à $60^{\circ}$ comparativement à $30^{\circ}$. La valeur uEN chez les enfants était basse avant $60 \%$ de GC, mais elle a augmenté nettement après $60 \%$ GC. Dans l'ensemble, un CoM semblable à celui des adultes a été partiellement détecté chez des enfants d'âge préscolaire en bonne santé lors de tâches de démarche variées. Cependant, des distinctions existaient, démontrant que les stratégies de compensation de ces enfants étaient encore en développement. MOTS CLÉS : centre de masse, développement des enfants, stratégie compensatoire, longueur de la foulée, trajectoires courbes

\footnotetext{
* Correspondence to: Assoc. Prof. Dr. Jin ZHOU, National Engineering Laboratory for Clean Technology of Leather Manufacture, Sichuan University; Chengdu 610065, P. R. China, zj_scu@scu.edu.cn
} 


\section{INTRODUCTION}

Motion is an essential ability in the development of children [1], and it is the outcome of complicated coordination within neural, muscle and skeletal systems. After the first step moved forward, young toddlers would repeat it in their lifetime. Commonly, toddlers were eager to establish their basic kinematics and kinetics format during first 5-6 months after independent walking $[2,3]$, or even earlier, where Hallemans [4] reported young toddlers already grasped the roll over gait pattern in their four months after independent walking. However, children were still in the further fine-turning develop process: ability to control gait and achieve a better coordination within limbs. On the one hand, adult's like length, width and frequency of gait were obtained after the age of 13 [5]; on the other hand, further development was aimed to obtain an economical energy cost and make the walking more efficiency $[6,7]$, where central nervous system coordinated various parts of the body so as to accomplish actions as well as achieving the minimum consumption of energy $[8,9]$. Although various approaches could be used in the assessment of children develop in motion, Centre of Mass (COM) was a superior one and it could be used to quantify the biomechanics issues, such as kinematic and balances of wholebody motion. Vlutters et al. [10] predicted pelvis perturbation by COM velocity; meanwhile Smith and Lynnelle [11] disclosed gender differences existed during walking in pelvic motion. Yamamoto even indicated that substantial effects of knee behavior on the COM kinematic in quiet standing [12]; Wada et al. [13] analyzed the COM movement and kinematic changes in rotation condition, and they found significant correlation between lateral COM and rotational side. Moreover, Hernández et al. found that the reduced acceleration of COM in mediolateral direction can be assisted to comprehend the walking balance issues in elder group [14]. Additionally, the COM was used to quantify the effect of the exoskeleton robotic device on the walking of the wearers $[15,16]$. In terms of optimization algorithm for COM calculation, Gard reported that when two dimensional COM data might produce errors when explaining the COM in three dimensional environment, and those results can be misleading [17]; so the trajectory in three-dimension would be more preferable for the COM analysis.

Engsberg was an early researcher to report the application of COM in assessment for children below knee amputation. Their results suggested that COM of those children was lower and anterior than in healthy children [18]. Moreover, in terms of children with cerebral palsy, Bennett et al. [19] found the intervention can help the patient to utilize kinetic energy in push-off walking; Jing [20] examined the COM of spastic hemiplegia children and their findings implied that trailing leg taken the leading role of propelling the COM motion [20]. Stride length and curve turning represented two kind of changes and they were common motions in daily life. The success finish of these gaits represented a senior ability of motion control. However, the above literature studies did not explain the compensative strategies of healthy children when they cope with the changes of stride length and curve turning; further what those changes affected their COM performances were still not explicit.

Thereby, the purpose of our study was to systematically investigate the influence of the stride length and curve turning changes on their COM performances and so as to disclose the basic regulation of the compensative strategies in healthy children.

\section{EXPERIMENTAL}

\section{Subjects}

Since children aged around 6 are still in the period when motion is developing, the findings of COM compensative strategies of children when they are facing the change of stride length and curve turning are meaningful. Ten healthy children aged around 6 (Male: Female $=1$ : 1 , Mean age $(S D)=6.0(0.0)$ years, weight $(S D)=19.0(2.7) \mathrm{kg}$, height $(S D)=112.5(5.7)$ 
$\mathrm{cm}$, foot length $(\mathrm{SD})=59.3(4.9) \mathrm{cm})$ and nine healthy adults as control group (Male: Female=5: 4, Mean age $(S D)=34.6(11.0)$ years, weight $(S D)=58.3(6.7) \mathrm{kg}$, height $(S D)=166.4(8.0) \mathrm{cm}$, foot length $(S D)=84.5(6.4) \mathrm{cm}$ ) participated in this study. The criteria for inclusion are shown below: (1) without foot deformities or injuries in the last year; (2) walk independently; (3) without abnormal gait patterns, such as a crouching gait or equines. With the introduction to the parents of the children and after obtaining their formal approvals, all the tasks were executed following the principles of Helsinki Declaration.

\section{Motion Capture of Subjects' COM}

The model of the pelvic region was first established following the instruction of Coda Motion System (Coda Motion cx1, Charnwood Dynamics Ltd., United Kingdom), where four markers were marked on the left and right anterior-posterior of pelvic region (Figure 1, marker1: anterior left of pelvis; marker2: anterior right of pelvis; marker3: the posterior right of pelvis; marker4: the posterior left of pelvis), and then the COM was defined as the central point of the pelvic model. Five gait tasks were defined as below:

- Straight walking (SW): Subjects walked at their self-selected speed in straight direction, also represented $0^{\circ}$ curve turning tasks.

- Long stride walking (LS): Subjects walked as their $150 \%$ stride length in the straight direction.

- Short stride walking (SS): Subjects walked as their $50 \%$ stride length in the straight direction.

- $30^{\circ}$ curve turning $\left(30^{\circ} \mathrm{CT}\right)$ : Subjects walked as their self-selected speed turning to $30^{\circ}$ curve direction.

- $60^{\circ}$ curve turning $\left(60^{\circ} \mathrm{CT}\right)$ : Subjects walked as their self-selected speed turning to $60^{\circ}$ curve direction.

Gait tasks were randomly arranged to the participants and a $6 \mathrm{~m}$ treadmill (Figure 2) was used in our test. Subjects changed their clothes to our tight ones when they came to the laboratory, and they walked at their self-selected speed. A 3-5 minutes warm-up was provided and at least five successful trails were obtained in each task.

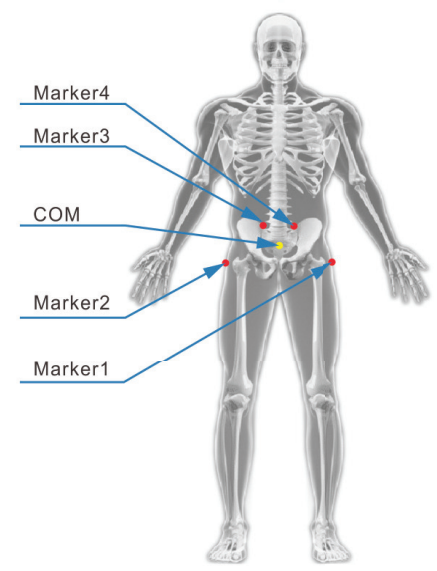

Figure 1. Demonstration of how the pelvic region was marked and the Centre of Mass was calculated

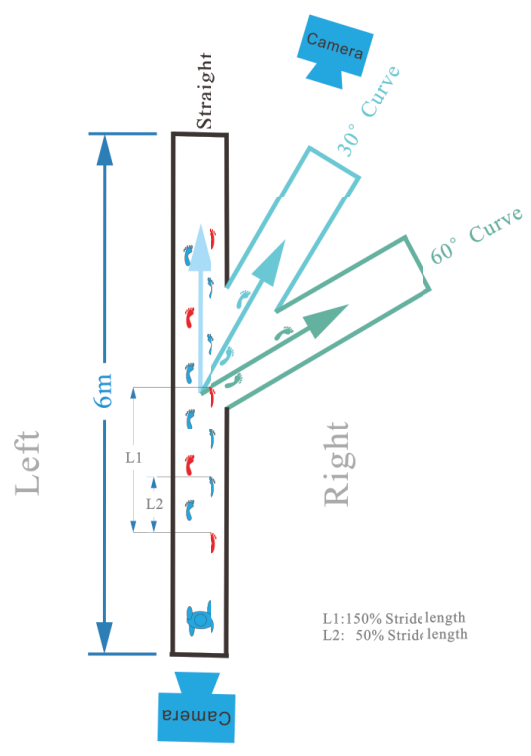

Figure 2. Gait tasks executed in the study. (subjects walked following the arrow on the ground, straight direction was used for straight walking; in terms of stride length tasks, subjects performed their short step (SS) gait follow the red and blue foot prints, and long stride (LS) walking only in red foot prints. Another two treadmills were used for curve turning task.) 


\section{Data Processing and Statistic Analysis}

A $6 \mathrm{~Hz}$ cut off strategy was firstly applied in the period of data processing, then threedimensional coordinates of COM were obtained by utilizing the algorithm of the Coda system (1.02, Charnwood Dynamics Ltd., United Kingdom). X and $Z$ displacement of COM were first considered and their means and standard deviation (SD), as well as the range of motion (ROM) and time to peak value (TPv) in a gait cycle were calculated; meanwhile energy issues of COM such as energy kinematics. The normalization procedures were executed in order to achieve a comparable result: $X$ and $Z$ displacement of COM was divided by leg length of each subject and transfer into $X$-rel and Z-rel variables [21]; then the energy variables were divided by their body weight and were transferred into unit ones: $\mathrm{uEk}\left(E_{k}\right), \mathrm{uEg}\left(E_{g}\right)$ and uEN ( $E)$ were computed (Formula 1-3) [19].

Gait cycle of each test was also normalized into 100 points $(\% \mathrm{GC})$.

$E_{k}=0.5 v^{2} E_{k}=0.5 v^{2}$

$E_{g}=g h E_{g}=g h$

$E=E_{k}+E_{p} E=E_{k}+E_{p}$

All those data were computed under the environment of SPSS (22.0, IBM, USA), with significant level of 0.05 and confident interval of $95 \%$.

\section{RESULTS AND DISCUSSIONS}

\section{Results}

COM Solution when the Stride Length Changed

Generally, in SW, COM of children moving around the center line of motion, while that of adult group shifted to the left side (Figure 3); meanwhile, as the stride length increased, children's ROM increased as well (SS ROM(SD) $=0.21(0.07), S W=0.33(0.12)$ and $\mathrm{LS}=0.57(0.21))$. Changed stride length advanced the first TPv in both SS and LS, comparing with SW (the $1^{\text {st }}$ peak of SW is $28 \%$ GC, SS is $26 \%$ GC, LS is $16 \% \mathrm{GC}$ ); further, the second TPv was delayed in SS and advanced in LS (the $2^{\text {nd }}$ peak of SW is $69 \% \mathrm{GC}$, SS is $75 \% \mathrm{GC}$, LS is $67 \% \mathrm{GC}$ ). In contrast with their peer adults group, similar COM trajectory in medio-lateral were found for the three gait types, as well as ROM, SD and TPv, totally adults showed larger ROM and range than children. In terms of sagittal plane, amplitude of COM, as well as its ROM and SD promoted both in child and adult groups (SS mean (SD, ROM) is $0.009(0.005,0.018)$, SW is $0.011(0.008,0.024$; LS is $0.035(0.021,0.07))$ as the stride length increased (from SS to SW to LS). Except the child's SS whose time to the $1^{\text {st }}$ peak was extended, TPV of SW and LS were similar (P1 of SS $=7 \% \mathrm{GC}, \mathrm{SW}=4 \% \mathrm{GC}$, LS $=4 \% \mathrm{GC}$; $\mathrm{P} 2$ of $S S=38 \% G C, S W=27 \% G C, L S=27 \% G C$ ).

In energy conversion, the children's uEn overall increased as the stride length prolonged; their volume of uEn in LS was lower than that of adults, whereas, similar uEn performances were found in SS and SW between the children and adults. 

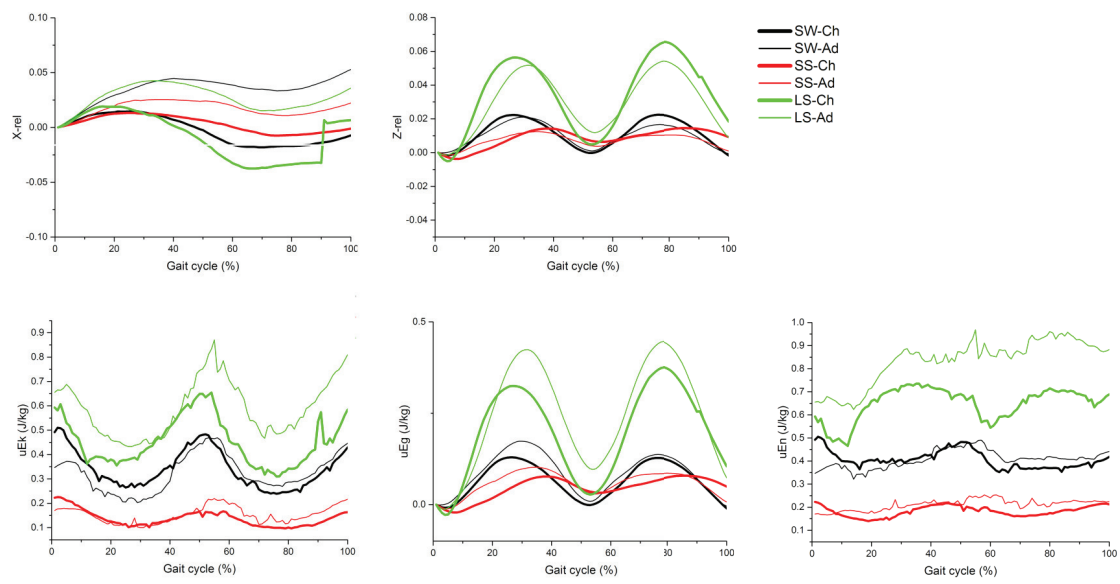

Figure 3. Results of Centre of Mass when coping with different stride length. (SW-Ch means children in SW tasks, SW-Ad means adults in SW tasks; SS-Ch means children in SS tasks, SS-Ad means adults

in SS tasks; LS-Ch means children in LS walk tasks, LS-Ad means adults in LS tasks; a is the X-rel displacement of COM in coronal plane, $b$ is the Z-rel displacement of COM in sagittal plane, $c$ is the uEk changes in one GC, $d$ is the uEg changes in one GC, e is the uEn changes in one GC).

\section{COM Solution while Curve Turning}

As the curve turning aggregated, child's COM shifted gradually to the curve direction (right) since $10 \% \mathrm{GC}$ (Figure 4); further dramatic change occurred at $60 \% \mathrm{GC}$, where a larger COM deviation was found in $60^{\circ}$ than that of $30^{\circ}$. In adult peer groups, a smaller deviation was recorded while turning in $30^{\circ}$ ( $\mathrm{ROM}=0.193$ For 30-Ad V.S. ROM=0.356 For 30-Ch). The amplitude of COM while turning curves showed that child lifted their COM in a high position in contrast with SW, as well as with their adults group. Further, TPv would delay as the angle of curve increased.

Energy transferred while curve turning indicated that with the increase of curvature $\left(0^{\circ}\right.$ $\left.30^{\circ}-60^{\circ}\right)$, uEk decreased and the uEg increased; nevertheless, adult group could maintain both the uEk and uEg while the process of walking direction changed. In uEk of child, TPv in $30^{\circ}$ and $60^{\circ}$ postponed relative to the SW; moreover, as the curving turning increases, the total $u E n$ of children was lowered before $60 \% \mathrm{GC}$; after $60 \% \mathrm{GC}$, $30^{\circ}>$ straight walking $>60^{\circ}$ could be obtained. a
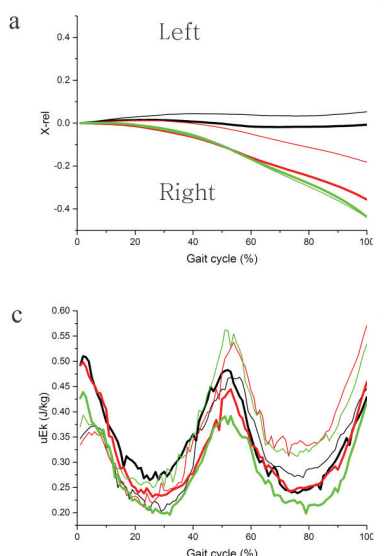
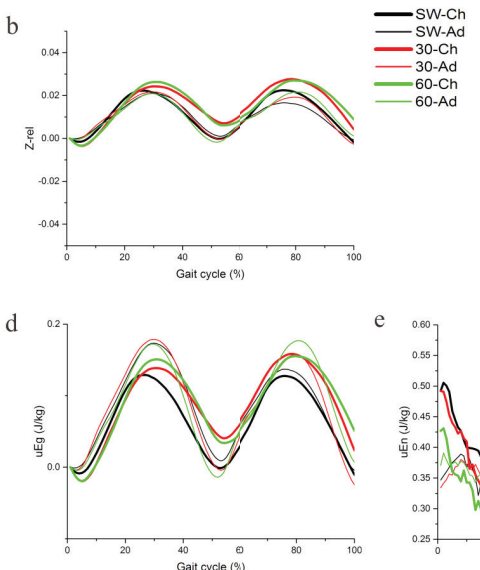

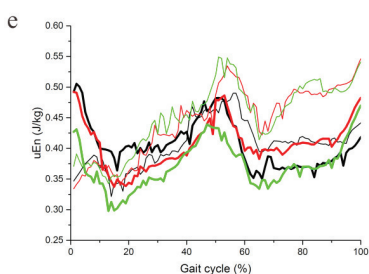

Figure 4. Results of Centre of Mass when coping with varied curve turning tasks. (SW-Ch means children in SW task, SW-Ad means adults in SW task, 30-Ch means children in 30CT task, 30-Ad means adults in 30CT task, 60-Ch means children in 60CT task, 60-Ad means adults in 60CT task; a is the X-rel displacement of COM in coronal plane, $b$ is the Z-rel displacement of COM in sagittal plane, $c$ is the uEk changes in one GC, $d$ is the $u E g$ changes in one GC, e is the $u E n$ changes in one GC.) 


\section{Discussion}

In our study, we investigated COM compensative strategies of children when they are coping with the change of stride length (SS and LS) and curve turning $\left(0^{\circ}-30^{\circ}-60^{\circ}\right)$ and the trajectory of COM in sagittal and coronal plane, uEn, uEk and uEg conversion while the critical gait period were analyzed. Those findings were helpful for us to comprehend the mechanism of gait adjustment in children, so as to understand their development in motion.

In the viewpoint of COM, children finished their gait through those events [4]: heel contact, toe contact, heel off, toe off, heel contact. During single-support phase, the leading leg was contacting with the ground and trailing leg went forwards by rotating the pelvis; at the same time, COM showed a tendency towards the leading leg and COM crossed the middle of central axis, then it reversed following the toe-off of the leading leg. When the stride length increased/decreased, an additional stretch of leg was required to rise/ descend the thigh so as to increase/decrease the height of COM. Meanwhile, enhanced stretch motion also postponed the key gait events in coronal plane ( $X$ direction) and sagittal plane ( $Z$ direction). Further, the uEk and uEn increased/ decreased as the added/shorted stride length performed, those changes also accelerate the walking velocity [22]. Our above findings also approved that adult-like ability in motion was not fully mastered in children aged 6 and it was in accordance with Jianhua et al. [23] and Beerse [19], whose studies disclosed that children at 5-11 ages are still developing their motion ability and they would spend 10 years to gain an adultlike variability-partitioning capability.
When turning a curve, the trailing leg would stretch much more, so as to generate sufficient rotate motion to complete the curve turning. Our results showed that the leading leg of children started swing earlier than their adult's counterparts, at round $60 \% \mathrm{GC}$. This phenomenon implied that when they decided to increase turning curve, they usually need more time to make adjustment, in order to finish the gait successfully, they have to do it earlier than their normal situation (such as SW); moreover, our outcomes also suggested that the ability of children to finish the sharp turn was still developing. Additionally, delayed TPV and increased height of COM in sagittal plane of children were the results of the increased stretch and pelvic rotation while curve turning and a lower uEk and uEn can be explained that children slow down their speed during this difficult curve turning tasks [22]. However, in curve turning, adults showed a stable COM pattern, even in the energy issues, which implied that curve turning tasks were easy for them as they were confident with their body size, as their past experiences and their better body coordination ability [22]. Therefore, the adults didn't need to stretch their leg as hard as children and to choose an economical gait [7].

In this study, two limitations existed, and they need to be declared before comprehending our results: (1) markers were set on tight clothing rather than skin, which would cause movement of the marker while walking; (2) model of COM in our study was a little different from the literature, such as Bennett [19], Eames [24] and Jensen [25], distinctions in the results might exist.

Table 1: Mean, SD and range of COM parameters

\begin{tabular}{|c|c|c|c|c|c|c|c|c|c|c|}
\hline & \multicolumn{2}{|l|}{ X-rel } & \multicolumn{2}{|c|}{ Z-rel } & \multicolumn{2}{|c|}{$\mathrm{uEk}(\mathrm{J} / \mathrm{kg})$} & \multicolumn{2}{|c|}{$\mathrm{uEg}(\mathrm{J} / \mathrm{kg})$} & \multicolumn{2}{|c|}{ uEn(J/kg) } \\
\hline & Mean $\pm S D$ & Range & Mean $\pm S D$ & Range & Mean \pm SD & Range & Mean $\pm S D$ & Range & Mean \pm SD & Range \\
\hline SW-Ch & $-0.003 \pm 0.012$ & 0.033 & $0.011 \pm 0.008$ & 0.024 & $0.341 \pm 0.078$ & 0.271 & $0.066 \pm 0.047$ & 0.140 & $0.406 \pm 0.038$ & 0.155 \\
\hline SS-Ch & $0.003 \pm 0.007$ & 0.021 & $0.009 \pm 0.006$ & 0.018 & $0.137 \pm 0.032$ & 0.129 & $0.045 \pm 0.03$ & 0.101 & $0.182 \pm 0.023$ & 0.083 \\
\hline LS-Ch & $-0.008 \pm 0.021$ & 0.057 & $0.035 \pm 0.021$ & 0.071 & $0.456 \pm 0.104$ & 0.525 & $0.198 \pm 0.122$ & 0.404 & $0.918 \pm 2.657$ & 26.740 \\
\hline $30-\mathrm{Ch}$ & $-0.132 \pm 0.112$ & 0.356 & $0.015 \pm 0.009$ & 0.031 & $0.318 \pm 0.075$ & 0.267 & $0.089 \pm 0.051$ & 0.178 & $0.407 \pm 0.037$ & 0.155 \\
\hline $60-\mathrm{Ch}$ & $-0.146 \pm 0.134$ & 0.438 & $0.016 \pm 0.009$ & & $0.283 \pm 0.069$ & & $0.09 \pm 0.052$ & 0.175 & $0.373 \pm 0.038$ & 0.172 \\
\hline SW-Ad & $0.035 \pm 0.011$ & 0.053 & $0.01 \pm 0.007$ & 0.022 & $0.323 \pm 0.076$ & 0.266 & $0.085 \pm 0.054$ & 0.178 & $0.408 \pm 0.038$ & 0.169 \\
\hline SS-Ad & $0.017 \pm 0.007$ & 0.025 & $0.007 \pm 0.004$ & 0.014 & $0.153 \pm 0.034$ & 0.119 & $0.059 \pm 0.032$ & 0.114 & $0.211 \pm 0.023$ & 0.087 \\
\hline LS-Ad & $0.027 \pm 0.011$ & 0.043 & $0.03 \pm 0.017$ & 0.056 & $0.589 \pm 0.114$ & 0.438 & $0.246 \pm 0.142$ & 0.459 & $0.834 \pm 0.098$ & 0.345 \\
\hline 30-Ad & $-0.048 \pm 0.061$ & 0.193 & $0.011 \pm 0.007$ & 0.024 & $0.358 \pm 0.091$ & 0.360 & $0.087 \pm 0.061$ & 0.203 & $0.446 \pm 0.058$ & 0.212 \\
\hline $60-\mathrm{Ad}$ & $-0.148 \pm 0.141$ & 0.439 & $0.011 \pm 0.008$ & 0.023 & $0.365 \pm 0.084$ & 0.313 & $0.088 \pm 0.062$ & 0.191 & $0.453 \pm 0.056$ & 0.207 \\
\hline
\end{tabular}




\begin{tabular}{|c|c|c|c|c|c|c|c|c|c|c|c|c|c|c|}
\hline & \multicolumn{14}{|c|}{ TPV (GC\%) } \\
\hline & P1 & $\mathrm{P} 2$ & P1 & $\mathrm{P} 2$ & P3 & P4 & P1 & P2 & P3 & P4 & P1 & P2 & P3 & P4 \\
\hline SW-Ch & 28 & 69 & 4 & 27 & 53 & 76 & 2 & 25 & 52 & 76 & 4 & 27 & 53 & 76 \\
\hline SS-Ch & 26 & 75 & 7 & 38 & 56 & 85 & 2 & 33 & 58 & 81 & 7 & 38 & 56 & 86 \\
\hline LS-Ch & 16 & 67 & 4 & 27 & 53 & 78 & 3 & 22 & 54 & 76 & 4 & 27 & 53 & 78 \\
\hline $30-\mathrm{Ch}$ & & & 5 & 30 & 54 & 78 & 2 & 26 & 53 & 73 & 5 & 31 & 54 & 78 \\
\hline $60-\mathrm{Ch}$ & & & 5 & 31 & 54 & 80 & 2 & 32 & 53 & 79 & 5 & 31 & 54 & 79 \\
\hline SW-Ad & 40 & 75 & 2 & 30 & 53 & 76 & 5 & 29 & 56 & 78 & 2 & 30 & 53 & 76 \\
\hline SS-Ad & 37 & 78 & 5 & 35 & 55 & 80 & 4 & 30 & 55 & 70 & 5 & 35 & 55 & 80 \\
\hline LS-Ad & 34 & 70 & 4 & 31 & 54 & 78 & 5 & 27 & 55 & 72 & 4 & 32 & 54 & 78 \\
\hline 30-Ad & & & 3 & 30 & 53 & 80 & 6 & 23 & 54 & 73 & 3 & 30 & 53 & 80 \\
\hline 60-Ad & & & 3 & 29 & 52 & 81 & 2 & 26 & 51 & 76 & 3 & 30 & 52 & 81 \\
\hline
\end{tabular}

SW-Ch: children in SW task; SS-Ch: children in SS task; LS-Ch: children in LS task; 30-Ch: children in 30CT task; 60-Ch: children in 60CT task; SW-Ad: adults in SW task; SS-Ad: adults in SS task; LS-Ad: adults in LS task; 30-Ad: adults in 30CT task; 60-Ad: adults in 60CT task. P1: Time to Peak value1Pv1;P2: Time to Peak value2;P3: Time to Peak value3;P4: Time to Peak value4.

\section{CONCLUSIONS}

When the stride length and curve turning changes, COM of healthy children in either coronal and sagittal plane, as well as the energy exchanges showed partly similar to those of adult. But some distinctions existed which demonstrated that compensative strategies of those children were still developing.

\section{Acknowledgements}

The authors appreciate all the children and adults who participated in this study. Funding: This work was supported by the National Natural Science Foundation of China [grant numbers 31700813]; China Postdoctoral Science Foundation [grant number 2015M571896].

\section{REFERENCES}

1. Cole, R., Sheila, J., Science, 1925, 61, 1588, xiv, https://doi.org/10.1126/science.61.1588.xiv.

2. Bril, B., Ledebt, A.J., Neurosci Biobehav Rev, 1998, 22, 4, 555-563, https://doi. org/10.1016/S0149-7634(97)00044-4.

3. Cioni, G., Duchini, F., Milianti, B., Paolicelli, P.B., Sicola, E., Boldrini, A., Ferrari, A., Early Hum Dev, 1993, 35, 3, 193-205, https://doi. org/10.1016/0378-3782(93)90106-5.

4. Hallemans, A., De Clercq, D., Otten, B., Aerts, P., Gait Posture, 2005, 22, 2, 107-18, https:// doi.org/10.1016/j.gaitpost.2004.07.010.

5. Lythgo, N., Wilson, C., Galea, M., Gait Posture, 2009, 30, 4, 502-506, https://doi. org/10.1016/j.gaitpost.2009.07.119.

6. Sánchez, N., Park, S., Finley, J.M., Sci Rep,
2017, 7, 1, 7682, https://doi.org/10.1038/ s41598-017-08147-y.

7. Reisman, D.S., Block, H.J., Bastian, A.J., J Neurophysiol, 2005, 94, 4, 2403, https://doi. org/10.1152/jn.00089.2005.

8. Forssberg, H., Nashner, L.M., J Neurosci, 1982, 2, 5, 545-52, https://doi.org/10.1523/ JNEUROSCI.02-05-00545.1982.

9. Barela, J.A., Jeka, J.J., Clark, J.E., Exp Brain Res, 2003, 150, 4, 434-42, https://doi. org/10.1007/s00221-003-1441-5.

10.Vlutters, M., van Asseldonk, E.H.F., van der Kooij, H., J Exp Biol, 2016, 10, 1514, https:// doi.org/10.1242/jeb.129338.

11.Smith, L.K., Lelas, J.L., Kerrigan, D.C., J Womens Health Gend Based Med, 2002, 11, 5, 453, https://doi. org/10.1089/15246090260137626.

12.Yamamoto, A., Sasagawa, S., Oba, N., Nakazawa, K., Gait Posture, 2015, 41, 1291-294, $\quad$ https://doi.org/10.1016/j. gaitpost.2014.08.016.

13.Wada, O., Tateuchi, H., Ichihashi, N., Gait Posture, 2014, 39, 1, 60-4, https://doi. org/10.1016/j.gaitpost.2013.05.030.

14.Hernández, A., Silder, A., Heiderscheit, B.C., Thelen, D.G., Gait Posture, 2009, 30, 2, 217, https://doi.org/10.1016/j. gaitpost.2009.05.006.

15.Aoyagi, D., Ichinose, W.E., Harkema, S.J., Reinkensmeyer, D.J., Bobrow, J.E., Proceedings of the 2005 IEEE 9th International Conference on Rehabilitation Robotics, 2005, 565-568.

16.Shamaei, K., Cenciarini, M., Adams, A.A., Gregorczyk, K.N., Schiffman, J.M., Dollar, A.M., 2015 IEEE International Conference on 
Robotics and Automation, 2015, 5557-5564.

17.Gard, S.A., Knox, E.H., Childress, D.S., J Biomech, 1996, 29, 10, 1387-1391, https:// doi.org/10.1016/0021-9290(96)00017-6.

18.Engsberg, J.R., Tedford, K.G., Harder, J.A., Arch Phys Med Rehabil, 1992, 73, 12, 1163-8.

19.Bennett, B.C., Abel, M.F., Wolovick, A., Frankling, T., Allaire, P.E., Kerrigan, D.C., Arch Phys Med Rehabil, 2005, 86, 11, 2189-2194, https://doi.org/10.1016/j.apmr.2005.05.012.

20.Feng, J., Pierce, R., Do, K.P., Aiona, M., Gait Posture, 2014, 39, 1, 570-576, https://doi. org/10.1016/j.gaitpost.2013.09.009.

21.Scrutton, D.R., Dev Med Child Neurol, 1969, 11, 1, 44.

22. Sutherland, D., J Bone Joint Surg $A m$, 1980, 62, 3, 336-53, https://doi. org/10.2106/00004623-198062030-00004.
23.Wu, J., McKay, S., Angulo-Barroso, R., Exp Brain Res, 2009, 196, 3, 329-339, https://doi. org/10.1007/s00221-009-1852-z.

24.Eames, M.H.A, Cosgrove, A., Baker, R., Hum Mov Sci, 1999, 18, 5, 637-646, https://doi. org/10.1016/S0167-9457(99)00022-6.

25.Jensen, R.K., J Biomech, 1986, 19, 5, 359-68, https://doi.org/10.1016/00219290(86)90012-6.

(C) 2019 by the author(s). Published by INCDTPICPI, Bucharest, RO. This is an open access article distributed under the terms and conditions of the Creative Commons Attribution license (http:// creativecommons.org/licenses/by/4.0/). 